\title{
27. STABLE ISOTOPIC STUDY OF CARBONATE MINERALS FROM THE BASALT FLOWS ON SUIKO SEAMOUNT: DSDP LEG 55, HOLE 433C
}

\author{
Judith McKenzie, Geologisches Institut, Eidg. Tech. Hochschule, Zürich, Switzerland
}

\section{INTRODUCTION}

Calcite in the cavities and veins of igneous rocks has long been recognized as an alteration by-product (Dana, 1892). Elementary mineralogy textbooks report that the most common occurrence of aragonite is in the cavities of basalts and andesites (e.g., Kerr, 1977). Therefore, it is not surprising to find both carbonate minerals in association with the moderately to extensively altered basalt flows recovered during deep sea drilling on Suiko Seamount in the Emperor Seamount chain (DSDP Leg 55, Hole 433C). The thickness and vesicularity of the flows, along with the presence of oxidized flow tops, indicate that the basalt erupted subaerially (Site 433 Report, this volume). The stable isotopic contents of the carbonate phases filling and lining the veins and vesicles denote the environment of alteration. An isotopic study was undertaken to secure supportive evidence for a subaerial period in the development of the seamount. Also, the subsequent alteration history after submergence may be interpreted from this isotopic record.

\section{SAMPLE DESCRIPTION}

Deep sea drilling at Suiko Seamount penetrated 387.5 meters of volcanic rock comprising more than 90 flow units. The basalts are $64.7 \pm 1.1 \mathrm{~m}$.y. old (Dalrymple et al., this volume), and are capped by middle to upper $\mathrm{Pa}$ leocene shallow-water sediments. Varying degrees of alteration occur in the basalt cores (Site 433 Report, this volume). Calcium carbonate is pervasive throughout, in association with the moderately to extensively altered rocks. Calcite and aragonite criss-cross the basalt as veins and partially or totally line and fill the vesicles. No evidence of infiltration by a biogenic carbonate is detectable. The carbonate is a precipitate, and often occurs in conjunction with a grayish green smectite. The minerals are all presumably the products of basalt alteration.

Visual descriptions of the studied carbonates are given in Table 1. Also included in Table 1 are the results of X-ray diffraction scans between $2 \theta$ values of $25^{\circ}$ and $35^{\circ}$, which were completed to determine the carbonate mineralogy. Calcite, high-Mg calcite, and aragonite were recorded.

Micrographs from selected thin sections were made to illustrate the most prominent carbonate phases. Plate 1, Figure 1 shows subhedral crystals of aragonite. The clay mineral, probably smectite, is visible as rosettes of radiating needles positioned between the aragonite and basalt. The micrograph in Plate 1, Figure 2 shows a vein composed of fibrous calcite with the long axes of the crystals oriented perpendicular to the vein walls. Subhedral aragonite crystals grow along and away from the center of the vein. The aragonite appears to be replacing the fibrous calcite. Aragonite was identified using Feigel's solution (Friedman, 1971), which stains aragonite black, leaving the other carbonate minerals untouched. Plate 1, Figure 3 is a micrograph of anhedral calcite from a blocky vein. With cross-polarized light, the vein filling appears to be radiaxial fibrous spar.

The precipitation of aragonite rather than calcite in the veins and vesicles of the basalt is probably a result of $\mathrm{Mg}$ ions inhibiting calcite formation (Bischoff and Fyfe, 1968). Alteration of the basaltic minerals releases $\mathrm{Mg}$ ions to the pore waters. The inhibitory action of $\mathrm{Mg}$ ions could also explain the apparent conversion of fibrous calcite to aragonite (Plate 1, Figure 2). The association of crystalline aragonite with peridotite exposed on the ocean floor has previously been observed in dredge samples (Thompson, 1972).

\section{STABLE ISOTOPE ANALYSES}

Calcium carbonate samples were collected randomly from the basalt sequence cored at Hole 433C, and were analyzed for their stable isotope content according to the traditional method utilizing the release of $\mathrm{CO}_{2}$ gas (McCrea, 1950). The gas was analyzed with a Micromass 903, a triple-collector mass spectrometer, and appropriate correction factors were applied (Craig, 1957). The results are expressed as per mil deviations from the PDB isotopic standard: $\delta=\left[\left(\mathrm{R}_{\text {sample }} / \mathrm{R}_{\text {standard }}\right)-1\right] \times$ $10^{3}$ where $\mathrm{R}$ is ${ }^{13} \mathrm{C} /{ }^{12} \mathrm{C}$ or ${ }^{18} \mathrm{O} /{ }^{16} \mathrm{O}$. The precision of the measurements, a standard deviation of the mean calculated for replicate analyses, is $\pm 0.02 \%$ for $\delta^{13} \mathrm{C}$ and $\pm 0.03 \%$ for $\delta^{18} \mathrm{O}$. The results are tabulated in Table 1 and graphed $\left(\delta^{18} \mathrm{O}\right.$ vs. $\left.\delta^{13} \mathrm{C}\right)$ in Figure 1.

Several trends are discernible in the stable isotope data. The high-Mg calcite sample $(40-1,80-82 \mathrm{~cm})$ has negative $\delta^{18} \mathrm{O}$ and $\delta^{13} \mathrm{C}$ ratios. The fibrous carbonate veins $(10-3,140-143 \mathrm{~cm}, 10-4,53.5-56 \mathrm{~cm}, 10-4$, 132-135 cm, 23-5, 145-146 cm, 24-1, 35-36 cm, 24-1, 41-42 cm, 27-2, 48-50 cm, and 27-3, 19-21 cm) have negative $\delta^{13} \mathrm{C}$ ratios, except for one sample (21-3, 63-64 $\mathrm{cm}$ ), which has a positive value. The remaining samples of blocky carbonate and dog-tooth spar (10-3, 148-149 $\mathrm{cm}, 11-3,25-30 \mathrm{~cm}, 11-3,52-54 \mathrm{~cm}, 11-4,86-87 \mathrm{~cm}$, 20-2, 30-31 cm, 21-2, 84-86 cm, 24-1, 63-64 cm, 26-3, $101-104 \mathrm{~cm}, 31-2,92-94 \mathrm{~cm}, 32-3,78-80 \mathrm{~cm}, 33-2,0-5$ 
TABLE 1

Analytical Data and Descriptions for Hole 433C Interbasalt Carbonates

\begin{tabular}{|c|c|c|c|c|c|c|}
\hline $\begin{array}{c}\text { Sample } \\
\text { (Interval in } \mathrm{cm} \text { ) }\end{array}$ & Flow Unit & $\delta 18_{\mathrm{OPB}}$ & ${ }^{\delta 13} \mathrm{CPDB}$ & $\%$ Calcite & $\%$ Aragonite & Description \\
\hline $10-3,140-143$ & $4 \mathrm{E}$ & +0.07 & -2.37 & 82 & 18 & Satiny white fibrous vein \\
\hline $10-3,148-149$ & $4 \mathrm{E}$ & -0.11 & +1.10 & 100 & - & White blocky vein \\
\hline $10-4,53.5-56$ & $4 \mathrm{~F}$ & +0.48 & -2.12 & 100 & - & Satiny white fibrous vein \\
\hline $10-4,132-135$ & $4 \mathrm{H}$ & +0.19 & -0.86 & 65 & 35 & Satiny white fibrous vein \\
\hline $11-3,25-30$ & 7 & +0.16 & +2.54 & 10 & 90 & Pinkish white, blocky vesicle filling \\
\hline $11-3,52-54$ & 7 & +0.07 & +1.44 & - & 100 & Clear blocky vein \\
\hline $11-4,86-87$ & 8 & +1.52 & +1.02 & 100 & - & White, dog-tooth spar, vesicle lining \\
\hline $20-2,30-31$ & $15 \mathrm{~B}$ & +0.76 & +1.01 & 100 & - & White blocky vein \\
\hline $21-2,84-86$ & Pumice-Lapilli & +0.88 & +1.13 & 100 & - & White, dog-tooth spar, vesicle lining \\
\hline $21-3,63-64$ & 17 & +0.43 & +0.72 & 100 & - & Satiny white fibrous vein \\
\hline $23-5,145-146$ & $19 \mathrm{C}$ & -0.12 & -1.50 & - & 100 & Satiny white fibrous vein \\
\hline $24-1,35-36$ & 19D & +0.13 & -1.69 & 100 & - & Satiny white fibrous vein \\
\hline $24-1,41-42$ & 19D & +0.25 & -0.62 & 14 & 86 & Satiny white fibrous vein \\
\hline $24-1,63-64$ & 19D & +0.35 & +1.98 & - & 100 & White blocky vein \\
\hline $26-3,101-104$ & 22 & +0.27 & +1.11 & 100 & - & Clear, dog-tooth spar, vesicle lining \\
\hline $27-2,48-50$ & $24 \mathrm{~A}$ & -0.52 & -2.20 & - & 100 & Satiny white fibrous vein \\
\hline $27-3,19-21$ & $24 \mathrm{~A}$ & -0.03 & -2.04 & 100 & - & Satiny white fibrous vein \\
\hline $31-2,92-94$ & 28 & -0.23 & +1.21 & 100 & - & Clear, dog-tooth spar, vesicle lining \\
\hline $32-3,78-80$ & $28 \mathrm{~F}$ & -1.36 & +0.48 & 100 & - & White blocky vein \\
\hline $33-2,0-5$ & 30 & +0.08 & +1.53 & 100 & - & White, dog-tooth spar, vesicle lining \\
\hline $34-6,100-102$ & 35 & -0.22 & +1.62 & 100 & - & White, dog-tooth spar, vesicle lining \\
\hline $35-1,82-84$ & 35 & +0.00 & +1.59 & 100 & - & White, dog-tooth spar, vesicle lining \\
\hline $39-7,56-58$ & 49 & -0.14 & +1.10 & 100 & - & Clear, dog-tooth spar, vesicle lining \\
\hline $40-1,80-82$ & 49 & -1.34 & -3.46 & $100^{\mathrm{a}}$ & - & Greenish white rosettes in clay matrix \\
\hline $46-4,45-46$ & $63 \mathrm{~B}$ & -0.76 & +1.64 & 100 & - & White, dog-tooth spar, vesicle lining \\
\hline $47-3,68-71$ & $63 \mathrm{C}$ & -0.72 & +1.10 & 100 & - & White, radiating needles, vesicle filling \\
\hline $48-3,102-104$ & $65 \mathrm{~A}$ & -1.01 & +1.19 & 100 & - & White, blocky vesicle filling \\
\hline $49-1,48-50 a$ & 66 & -1.56 & +0.28 & 100 & - & White, blocky vesicle filling \\
\hline $49-1,48-50 b$ & 66 & -1.52 & +0.30 & 100 & - & Yellow, rosette vesicle lining \\
\hline
\end{tabular}

aHigh-Mg calcite $(12.6 \% \mathrm{Mg})$

$\mathrm{cm}, 34-6,100-102 \mathrm{~cm}, 35-1,82-84 \mathrm{~cm}, 39-7,56-58 \mathrm{~cm}$, $46-4,45-46 \mathrm{~cm}, 47-3,68-71 \mathrm{~cm}, 48-3,102-104 \mathrm{~cm}$, and $49-1,48-50 \mathrm{~cm}$ ) all have positive $\delta^{13} \mathrm{C}$ ratios.

An oxygen-18 isotopic boundary apparently exists at Core 27. Independent of crystal habit, the carbonate minerals above Core 27 have relatively more positive $\delta^{18} \mathrm{O}$ ratios; those below have relatively more negative ratios. There is no detectable relationship between the stratigraphic positions of the carbonate minerals with respect to the flow boundaries and their stable isotopic contents.

\section{DISCUSSION}

The carbon- 13 content indicates the source of $\mathrm{CO}_{2}$ gas that is incorporated as carbonate ions into the crystal. Calcium carbonate precipitated in isotopic and chemical equilibrium with $\mathrm{CO}_{2}$ gas is enriched in carbon-13 by $10 \%$ (Emrich et al., 1970). For example, the $\delta^{13} \mathrm{C}$ ratio of calcium carbonate precipitated in equilibrium with atmospheric $\mathrm{CO}_{2}\left(-7.0 \%\right.$ ) at $20^{\circ} \mathrm{C}$ would be $+3.0 \%$. The $\mathrm{CO}_{2}$ generated from the decomposition of organic material is significantly depleted in carbon-13. A contribution of the "organic" $\mathrm{CO}_{2}$ to the carbonate precipitate diminishes its carbon- 13 content. In a study of carbonate rocks from the Cambrian to Tertiary, Keith and Weber (1964) found that the average $\delta^{13} \mathrm{C}$ ratio for those of marine origin is $+0.56 \pm 1.55 \%$ and that for those of fresh-water origin is $-4.93 \pm 2.75 \%$. The difference reflects the greater contribution of "organic" $\mathrm{CO}_{2}$ to the latter.

The isotopic values of the carbonate phases analyzed for this study separate the samples into two categories according to their carbon-13 content, as shown in Figure 1:

1) Negative carbon-13 ratios. Two types of samples contain negative $\delta^{13} \mathrm{C}$ ratios: the high-Mg calcite rosettes and the fibrous calcium carbonate (excluding Sample $21-3,63-64 \mathrm{~cm}$ ). These negative values are very strong indicators for an input of "organic" $\mathrm{CO}_{2}$. The high-Mg calcite (Sample $40-1,80-82 \mathrm{~cm}$ ) is the most likely to have had a fresh-water origin; both its carbon and oxygen isotopic contents classify it as a fresh-water carbonate, according to the scheme of Keith and Weber (1964). The fibrous carbonates with more positive $\delta^{18} \mathrm{O}$ ratios than the high-Mg calcite were probably formed in the shallow subtidal to supratidal to splash-water environments. $\mathrm{CO}_{2}$ depleted in carbon-13 would be readily available from fresh-water runoff or near-shore organic activity. The formation of aragonite or calcite fibrous cements in limestone voids has often been placed in this environment (Wolf, 1965, and Krebs, 1969). Also, the 111 meters of shallow-water sediments which overlie the basalt have a very homogeneous $\delta^{13} \mathrm{C}$ ratio of about $+1.0 \pm 0.2 \%$ (McKenzie et al., this volume). The dia- 


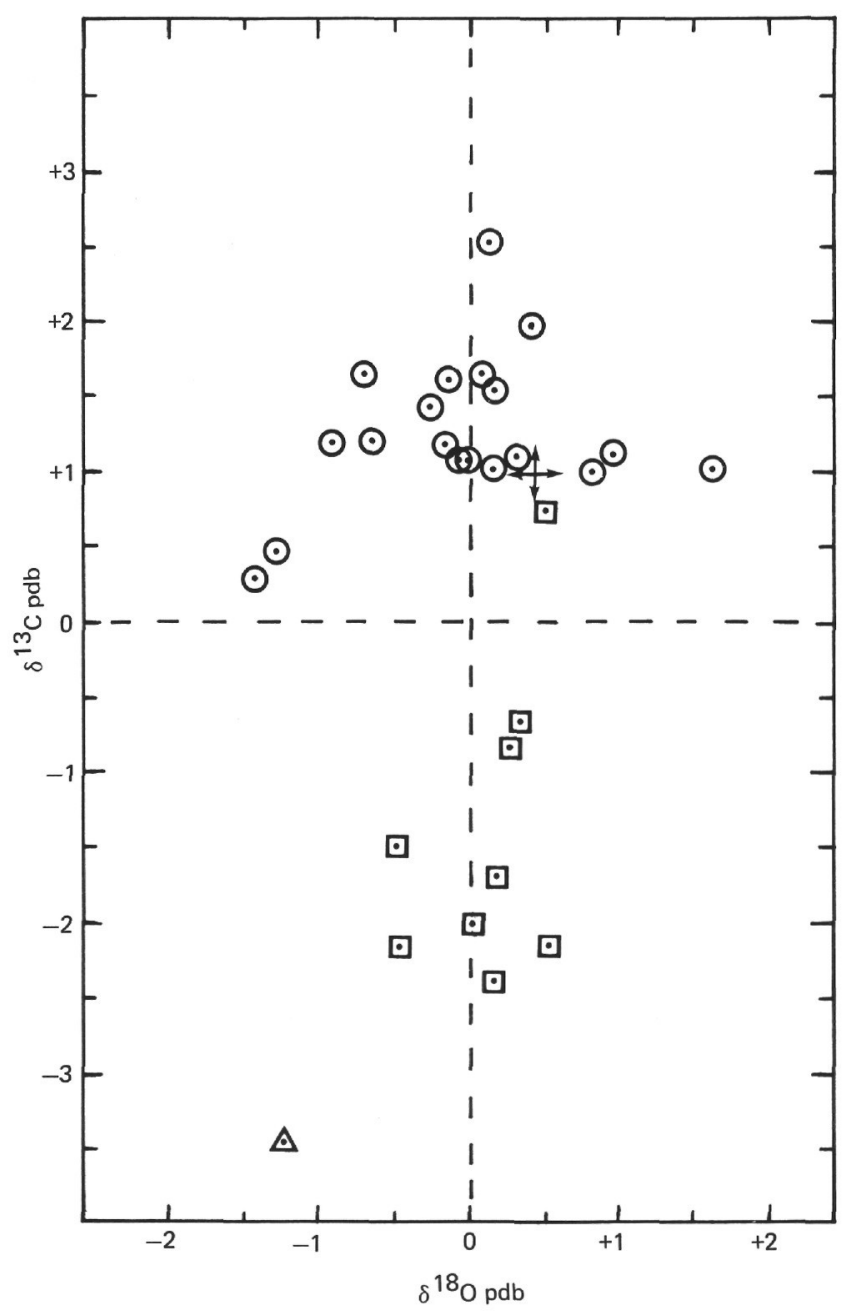

Figure 1: A plot of oxygen-18 vs. carbon-13 ratios for interbasaltic and overlying shallow-water carbonates from Suiko Seamount (DSDP Hole 433C). Symbols: (๑) fibrous carbonates, (๑) blocky or dog-toothed $(\Delta)$ high-Mg calcite rosette, and $(\leftrightarrow)$ an average shallow-water carbonate.

genesis of this material occurred in intermediate marine waters after cessation of shallow-water sedimentation and subsidence of the seamount. For this reason, it is proposed that the alteration of basalt, which resulted in precipitation of the carbon-13 depleted carbonate, preceded the major subsidence. This could explain the input of "organic" $\mathrm{CO}_{2}$ into the interbasalt carbonates, but not into the overlying shallow-water sediments.

2) Positive carbon-13 ratios. This second category of carbonates can be further divided into two types separated by a boundary lying between Cores 26 and 27, or approximately 336 meters below the sea floor. The carbonates above have relatively more positive $\delta^{18} \mathrm{O}$ ratios, and those below have relatively more negative $\delta^{18} \mathrm{O}$ ratios. The average $\delta^{13} \mathrm{C}$ ratio for both types is $+1.2 \pm$ $0.5 \%$, which is very close to the value for the overlying shallow-water sediments. Therefore, it is proposed that these carbonates result from the alteration of basalt after the onset of major subsidence of the seamount. The difference in the oxygen-18 isotopic compositions of the carbonates could have several origins, but is probably related to differing degrees of restriction of the pore waters. Submarine alteration of basalts to lowtemperature minerals depletes the oxygen-18 content of the water involved in the reaction (Lawrence et al., 1975 and Perry et al., 1976). If the pore waters have restricted communication with open sea water, the $\delta^{18} \mathrm{O}$ ratios of the carbonate precipitating from the isotopically depleted waters will mirror this diminution (Anderson and Lawrence, 1976). Perhaps the pore waters had more restricted circulation through the lower basalts than through the upper basalts. This could account for the relatively more negative oxygen-18 values of the lower carbonate precipitates. Other explanations for depleted oxygen-18 could be the presence of fresh-water or hydrothermal fluids, but diagenetically altered waters appear to provide the most likely reason when the homogeneity of the carbon-13 values is considered. Also, solutions originating from the basalt alteration took part in the later stage diagenesis of the overlying shallow-water sediments, which were cemented by calcite and phillipsite (McKenzie et al., this volume). This calcite cement has a slightly negative $\delta^{18} \mathrm{O}$ ratio $(-0.44 \% 0)$.

\section{CONCLUSIONS}

The presence of carbonate minerals in association with moderately altered basalts is not unexpected. In his description of basalts drilled beneath the limestone on Eniwetok Atoll, Macdonald (1963) describes carbonate veins which appear to be very similar to those found on Suiko Seamount. In the case of Eniwetok, it was concluded that alteration of the basalt and formation of the veins must have occurred when the top of the basalt was only slightly submerged below sea level. Stable isotopic evidence indicates that alteration of the Suiko basalts began very early, perhaps, while the basalts remained subaerially exposed. The alteration continued with submergence and produced carbonate minerals whose stable isotopic ratios represent at least two stages in the subsidence history of the seamount: early, shallowwater and later, deeper-water environments. The data clearly demonstrate, along with the other evidence gathered by Leg 55 investigators, that Suiko Seamount underwent subaerial and shallow-water periods in its genesis.

\section{ACKNOWLEDGMENTS}

I thank K. J. Hsü for his constructive review of this manuscript and J. Pika for the X-ray diffraction analyses. This work was supported by the Swiss National Science Foundation $2.420-0.75$ and $2.777-0.77$.

\section{REFERENCES}

Anderson, T. F. and Lawrence, J. R., 1976. Stable isotope investigations of sediments, basalts, and authigenic phases from Leg 35 cores. In Hollister, C. D., Craddock, C., et 
al., Initial Reports of the Deep Sea Drilling Project, v. 35: Washington (U.S. Government Printing Office), pp. 497505.

Bischoff, J. L. and Fyfe, W. S., 1968. Catalysis, inhibition, and the calcite-aragonite problem, American Journal of Science, v. 266 , pp. 65-79.

Craig, H., 1957. Isotopic standards for carbon and oxygen and correction factors for mass spectrometric analyses of carbon dioxide, Geochimica et Cosmochimica Acta, v. 12, pp. 133-149.

Dana, E. S., 1892. The System of Mineralogy of J. D. Dana 1837-1868, Descriptive Mineralogy, Sixth Edition: New York (John Wiley \& Sons).

Emrich, K., Ehhalt, P. H., and Vogel, J. C., 1970. Carbon isotope fractionation during the precipitation of calcium carbonate, Earth and Planetary Science Letters, v. 8, pp. 363-371.

Friedman, G., 1971. Staining. In Carber, R. E. (Ed.), Procedures in Sedimentary Petrology: New York (John Wiley \& Sons).

Keith, M. L. and Weber, J. N., 1964. Carbon and oxygen isotopic composition of selected limestones and fossils, Geochimica et Cosmochimica Acta, v. 28, pp. 1787-1816.

Kerr, P. F., 1977. Optical Mineralogy, Fourth Edition: New York (McGraw-Hill Book Company).
Krebs, W., 1969. Early void-filling cementation in Devonian fore-reef limestones (Germany), Sedimentology, v. 12, pp. 279-299.

Lawrence, J. R., Gieskes, J. M., and Broecker, W. S., 1975. Oxygen isotope and cation composition of DSDP pore waters and the alteration of layer II basalts, Earth and Planetary Science Letters, v. 27, pp. 1-10.

Macdonald, G. A., 1963. Petrology of the basalt beneath the limestones. In Schlanger, S. O., Subsurface Geology of Eniwetok Atoll, Geological Survey Professional Paper 260$B B$ : Washington (U.S. Government Printing Office), pp. 1038-1048.

McCrea, J. M., 1950. The isotopic chemistry of carbonates and a paleotemperature scale, Journal Chemical Physics, v. 18, pp. 849-857.

Perry, E. A., Jr., Gieskes, J. M., and Lawrence, J. R., 1976. $\mathrm{Mg}, \mathrm{Ca}$ and $18 \mathrm{O} / 16 \mathrm{O}$ exchange in the sediment-pore water system, Hole 149, DSDP, Geochimica et Cosmochimica Acta, v. 40, pp. 413-423.

Thompson, G., 1972. A geochemical study of some lithified carbonate sediments from the deep-sea, Geochimica et Cosmochimica Acta, v. 36, pp. 1237-1253.

Wolf, K. H., 1965. Littoral environment indicated by openspace structures in algal limestones, Palaeogeography, $\mathrm{Pa}$ laeoclimatology, Palaeoecology, v. 1, pp. 183-223.

\section{PLATE 1}

Thin-section photographs of carbonate minerals from basalt flows on Suiko Seamount, DSDP Leg 55.

Figure 1 Blocky aragonite vein (Sample 433C-11-3, 52-54 $\mathrm{cm})$ with smectite separating the carbonate and basalt (upper left corner). Left: plane polarized light. Right: cross-polarized light. Scale bar: 0.15 $\mathrm{mm}$.

Figure 2 Fibrous calcite vein (Sample 433C-10-3, 140-143 $\mathrm{cm}$ ) with aragonite growing along and away from the center of the vein. Left: plane polarized light. Right: cross-polarized light. Scale bar: $0.50 \mathrm{~mm}$.

Figure 3 Blocky calcite vein (Sample 433C-10-3, 148-149 $\mathrm{cm})$. Left: plane polarized light. Right: crosspolarized light. Scale bar: $0.50 \mathrm{~mm}$. 
PLATE 1
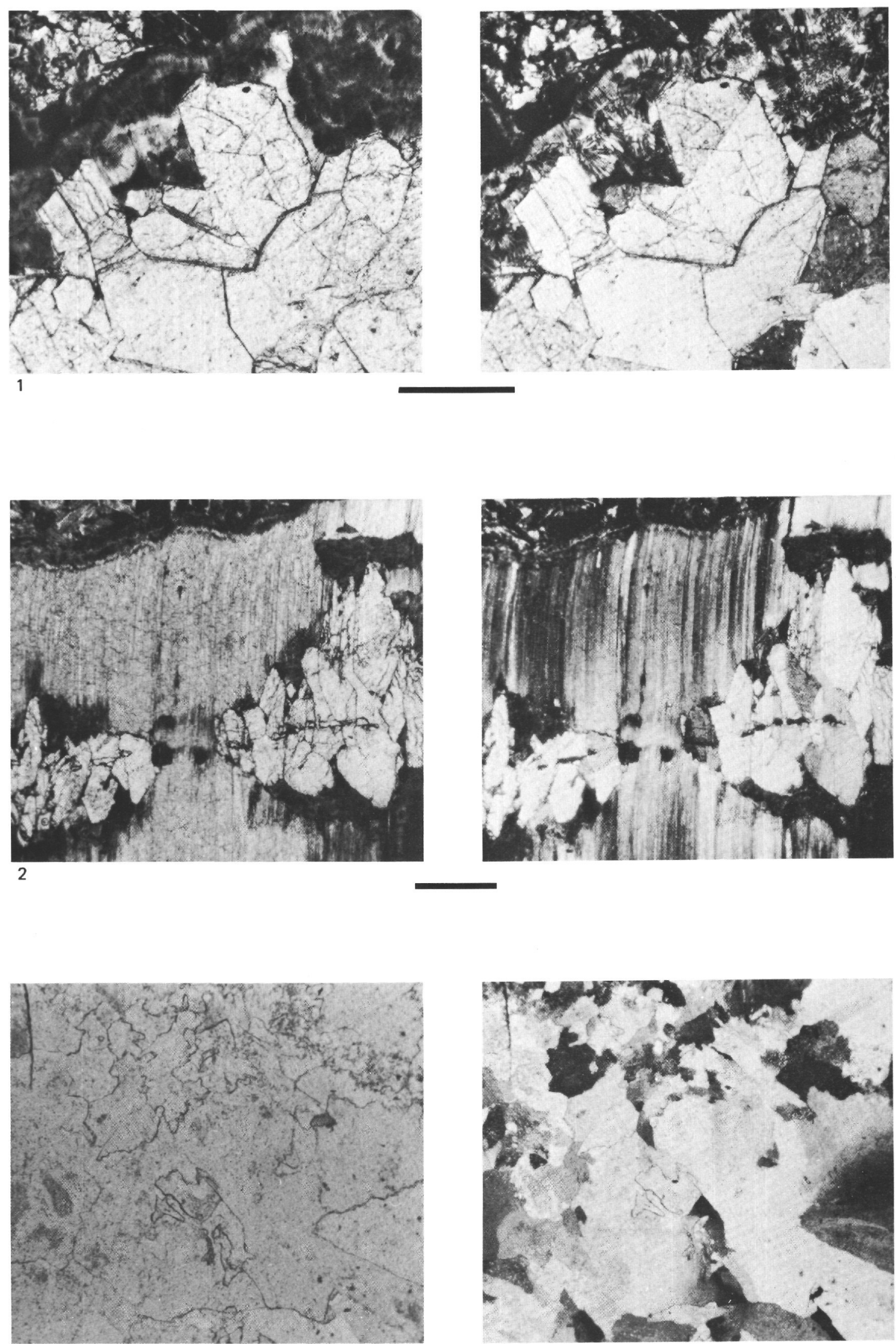